\title{
Coccidioidomycosis: skin manifestations and hypersensitivity syndromes
}

\author{
Coccidioidomicosis: manifestaciones cutáneas y síndromes de \\ hipersensibilidad
}

\author{
Melisa Mejía-Jiménez' ${ }^{1}$ Nora Cardona-Castro ${ }^{2}$ CvLAC
}

Fecha correspondencia:

Recibido: enero 28 de 2015.

Revisado: septiembre 11 de 2015.

Aceptado: octubre 20 de 2016.

Forma de citar:

Mejía-Jiménez M,Cardona-Castro

N. Coccidioidomycosis: skin manifestations and hypersensitivity syndromes. Rev CES Med 2016;

30(2): 188-199.

Open access

(c) Copyright

Licencia creative commons

Ética de publicaciones

Revisión por pares

Gestión por Open Journal System

ISSN 0120-8705

e-ISSN 2215-9177

Sobre los autores:

1. Dermatology Resident,

Universidad CES

2. MD, PhD, Researcher, Instituto Colombiano de Medicina Tropical, Universidad CES.

Comparte

70G.

\begin{abstract}
Coccidioidomycosis is caused by Coccidioides immitis and Coccidioides posadasii fungi, which are endemic in certain locations in the American continent. They produce an asymptomatic infection in the majority of the exposed population, and in a lower proportion, a self-limited influenza-like illness, pneumonia or dissemination. Skin compromise could be secondary to the infection by the fungus or by a hypersensitivity reaction to the pulmonary infection. Primary skin compromise produces a chancriform, self-limited lesion, and the dissemination to the skin commonly produces nodules and abscesses, with a tendency to form fistulas. The most common hypersensitivity reaction is erythema nodosum, which is considered a marker of good prognosis. Treatment depends on the localization of the infection, the presence of dissemination, and the clinical conditions of the patient.
\end{abstract}

Keywords: Coccidioides immitis, Coccidioides posadasii, San Joaquin Valley fever, erythema nodosum, hypersensitivity reactions.

\section{Resumen}

La coccidioidomicosis es causada por los hongos Coccidioides immitis y Coccidioides posadasii, los cuales son endémicos en determinadas localizaciones del continente americano. Producen infección asintomática en la mayoría de expuestos y en menor proporción cuadros gripales autolimitados, neumonía o diseminación. El compromiso en piel puede ser secundario a la infección por el hongo o por una reacción de hipersensibilidad a la infección pulmonar. El compromiso primario en piel produce una lesión chancreiforme, autolimitada y la diseminación a piel produce comúnmente nódulos y abscesos, con tendencia a la fistulización. La reacción de hipersensibilidad más común es el eritema nodoso, considerándose un marcador de buen pronóstico. El tratamiento depende de la localización de la infección, la presencia de diseminación y las condiciones clínicas del paciente.

Palabras clave: Coccidioides immitis; Coccidioides posadasii; Fiebre del Valle de San Joaquín; Eritema nodoso; Reacciones de hipersensibilidad. 
Coccidioidomycosis makes part of deep mycoses caused by Coccidioides immitis and Coccidioides posadasii dimorphic fungi, which are considered the primary pathogens because they affect immunocompetent people $(1,2)$. Both species produce an indistinguishable disease in humans, more commonly in the lungs, but occasionally with dissemination to other organs, including the skin.

\section{Introduction}

Coccidioidomycosis makes part of deep mycoses caused by Coccidioides immitis and Coccidioides posadasii dimorphic fungi, which are considered the primary pathogens because they affect immunocompetent people $(1,2)$. Both species produce an indistinguishable disease in humans, more commonly in the lungs, but occasionally with dissemination to other organs, including the skin. Multiple secondary hypersensitivity reactions to the infection with variable cutaneous manifestations have been described (ㄱ). It has also been called Posada-Wernicke disease, San Joaquin Valley fever, and desert rheumatism (4).

Coccidioidomycosis was reported for the first time by Posada and Wernicke in 1892, in a soldier from the El Chaco region (Argentina), who presented with warty lesions on the face and posteriorly died from disseminated infection. It was initially considered a parasite due to its similitude with those of the Coccidia genus. In 1900, Ophüls inoculated it in animals and could classify it as a dimorphic fungus and describe its life cycle. The distinction between both species of Coccidioides is relatively recent, taking into account that only until 2002, its genotypic differences were described $(1,2,5)$.

Coccidioides immitis and C. posadasii belong to the Dikaryomycota class, of the Onygenaceae family (to which other dimorphic fungi such as Paracoccidioides brasiliensis, Histoplasma capsulatum and Blastomyces dermatitidis belong). These are the only known species of the Coccidioides genus and their differentiation, apart from the geographical location where they are found, is genetic. The sexual phase has not been described, but molecular studies suggest it exists because genetic recombination has been proven, not only clonal expansion ().

The fungus has a life cycle with a saprophyte form found in its habitat, and a parasitic form in the host (figure 1). Its saprophyte form grows as elongated and septated hyphae, which liberate arthroconidia responsible for infection when they are weakened. In dry conditions, they could be viable for many years.

When inhaled, they enter the respiratory tract and arthroconidia start their growth in the terminal bronchioles forming the spherule, a structure which is exclusive to the Coccidioides genus and the infecting phase. The spherule expands in a four-day period and, by means of cellular division, it produces endospores that are liberated when the spherule breaks, with approximately 800 endospores by spherule (6). Daughter endospores restart their growth, expanding, and forming new spherules, thus perpetuating the reproduction of the fungus in the host (figure 1) (2).

Initially, the immune response is neutrophilic, and later, the resident macrophages in the lung phagocyte the endospores, and activate the specific T cells that start an immune response mediated by the cells with granuloma formations, in an attempt at controlling the disease (

Coccidioidomycosis is considered to be a disease limited to the American continent, given the fact that its etiological agent has not been isolated in other territories. The habitat of $\mathrm{C}$. immitis is to the south and center of California (where San Joaquin's Valley is localized) with extension to Baja California, while C. posadasii is found to the west and south of Arizona, east of Texas, Utah, Mexico, Central America, and South America (6). 


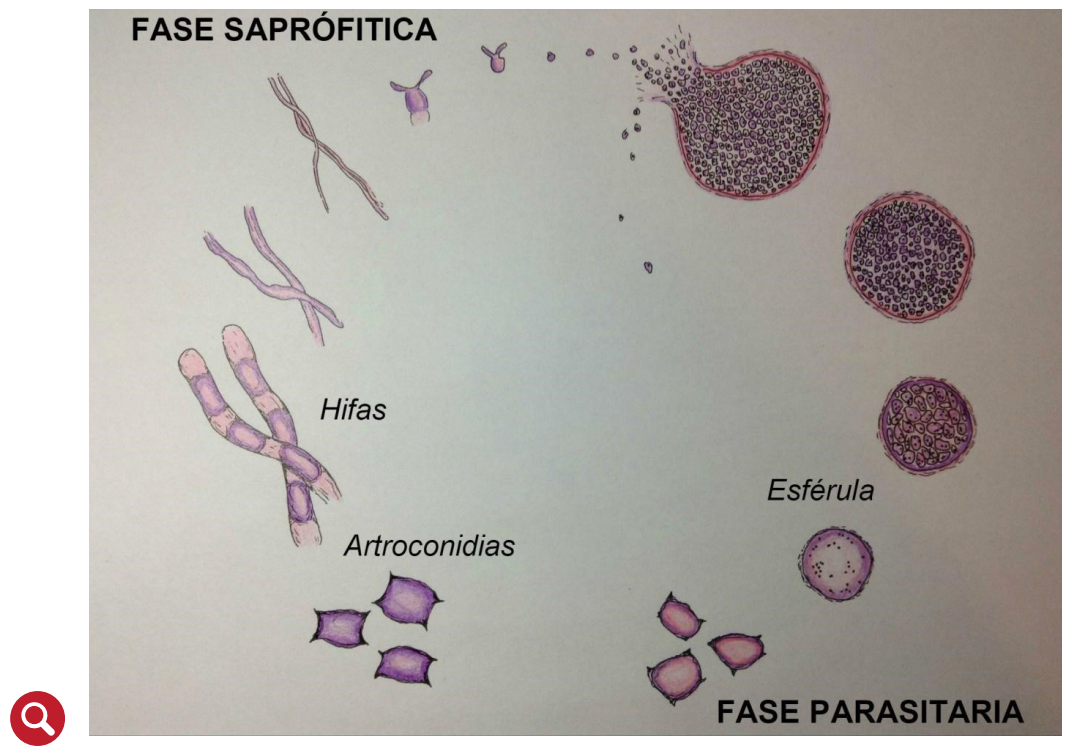

Figure 1. Life cycle. Illustration by Manuel Patiño Hoyos

Coccidioidomycosis may present as a self-limited pulmonary infection or may produce severe pulmonary compromise and dissemination to other organs.
Semi-desert conditions in the places mentioned above, low rain frequencies, poor vegetation, and alkaline soils make them ideal environments for the reproduction of the fungus ( $\underline{3})$.

Mexico has the highest incidence of coccidioidomycosis in Latin America, followed by Venezuela. In Colombia, it is a rare disease, with few cases reported in the departments of Magdalena and Cesar (2, $\underline{\mathbf{8}}-\underline{10})$. Coccidioidomycosis has been described in patients of all ages, including the elderly and children (11), but it is four times more common in men, associated to the jobs and activities performed in the natural habitat of the fungus (military personnel, peasants, builders, tourists, armadillo hunters), and in endemic zones it could be responsible for up to one third of the patients with lower respiratory tract symptoms $(\underline{8}, 12)$. Even though it is less frequent in women, they present a higher prevalence of hypersensitivity reactions erythema nodosum like (3).

Certain conditions and risk factors associated to the development and prognosis of the disease have been described. In Afro-American people, the risk of disseminated disease is 10 times higher, without a clear cause to date (므). In pregnant women it is specially severe in the third trimester and immediate postpartum, with a higher risk of severe and symptomatic disease. Consequences of the maternal disease on the newborn have not been reported (13).

The incidence of severe coccidioidomycosis in HIV infected patients has been reduced since the advent of the antiretroviral therapy, and when it presents, it is usually in patients without previous HIV diagnosis and low $\mathrm{CD}_{4}$ count (14).

\section{Clinical manifestations}

Coccidioidomycosis may present as a self-limited pulmonary infection or may produce severe pulmonary compromise and dissemination to other organs. Sixty per cent of patients exposed to the infection by the fungus are completely asymptomatic and a lower proportion has unspecified flu-like symptoms (25-40\%), which spontaneously improve in 2-3 weeks, without medical attention. Only 2\% presents with severe pulmonary compromise manifested with pneumonia and acute respiratory 
The dissemination to the skin compromises virtually any part of the body, but especially the face, neck, armpits, and groin. The most common presentations are papules, pustules, nodules, furuncles, verrucose plaques, abscesses, and ulcerations, with a tendency to fistulization and seropurulent drainage, and leaving retractile and deforming scars. distress syndrome, associated with hypersensitivity syndromes. Five per cent of patients persist with chronic symptomatology (12), consisting of cough, constitutional symptoms, and hemoptysis $(\underline{15}, \underline{16})$.

Only $0.2 \%$ of immunocompetent patients present with disseminated disease $(\underline{2}, 17)$, defined as compromise outside the thoracic cavity, but in immunosuppressed patients, it may be up to $50 \%$ (18). It usually occurs by hematogenous or lymphangitic dissemination, mainly to the skin, the central nervous system, manifesting as headache and hydrocephalus, and to the bones, with a penchant for axial structures such as the vertebrae, skull, sternum, and ribs (19-24).

\section{Cutaneous coccidioidomycosis}

Cutaneous manifestations of coccidioidomycosis can be divided into those which are caused by the infection of the tissue by the fungus (primary or disseminated), and those caused by changes reactive to pulmonary compromise. The former are usually caused by hematogenous dissemination, and rarely, by traumatic inoculation (25).

Primary cutaneous coccidioidomycosis: It is a rare entity, first described in 1926, and since then, only about 20 cases have been reported. It may appear after puncture traumatisms (cacti, plants) or accidental inoculation in the laboratory, usually with limb and face compromise. It usually presents as an ulcerous nodule, sometimes with a sporotrichoid pattern, with lymphadenopathies and adenitis. It is associated with a positive coccodiodin skin test and negative complement fixation titers. It does not usually disseminate and in immunocompetent people, there may be resolution without treatment (25).

The differentiation between a primary cutaneous coccidioidomycosis and a disseminated one without obvious pulmonary symptoms might be difficult, given the fact that their histology is the same and disseminated coccidioidomycosis may present a phenomenon called locus minoris resistentiae, where the organisms of the bloodstream have a predilection for lodging in areas with previous trauma (lacerations or punctures). If the lesions are multiple, verrucose, abscessed or of torpid course, they are possibly secondary to pulmonary dissemination (26).

The initial biopsy shows a dense lymphocyte, neutrophil, plasma cell infiltration, and numerous spherules. In chronic lesions, scarce microorganisms and a granulomatous inflammation with gigantic cells are observed (26-29).

Some diagnostic criteria have been described to consider a primary cutaneous compromise (30): absence of pulmonary disease history, clear history of traumatic inoculation, short incubation period (1-3 weeks) previous to the onset of the symptoms, initial chancriform lesion (nodule o asymptomatic plaque, indurated with central ulceration), lymphadenopathy or lymphadenitis, positive precipitins, initial positive coccodiodin skin test, and negative complement fixation titers, with posterior positive very low titers, and spontaneous healing in a few weeks in immunocompetent patients.

Disseminated cutaneous coccidioidomycosis: The dissemination to the skin compromises virtually any part of the body, but especially the face, neck, armpits,, and groin $(3,4)$. The most common presentations are papules, pustules, nodules, furuncles, verrucose plaques, abscesses, and ulcerations, with a tendency to fistulization and seropurulent drainage, and leaving retractile and deforming scars. They are usually asymptomatic. 
There is improvement of the cutaneous lesions and the pulmonary symptoms after five weeks of treatment with antifungals and topical steroids.
The biopsy shows epidermal hyperplasia and granulomatous and suppurative inflammation in the dermis and the subcutaneous cellular tissue. The spherules can be observed with special stains. If these are visible in the skin biopsy, we should thoroughly look for other dissemination sites $(\underline{16}, \underline{31})$.

\section{Hypersensitivity reactions by coccidioidomycosis}

They are more common in white women, presenting in $25 \%$ of affected patients, and its presence has been related with a good prognosis. They are believed to be secondary to a reactive cellular response against the fungus, and as such, no microorganisms are isolated in the lesions, and the treatment with azoles is not indicated.

Erythema nodosum: It is considered to be the most characteristic hypersensitivity reaction of coccidioidomycosis, usually associated with arthralgias and, occasionaIly, conjunctivitis (32). It is more common in women (25-50\% vs. 18\% in men) and it represents a delayed hypersensitivity reaction to various antigens in subcutaneous fat, and as such, it is associated to a positive response in the cutaneous reaction to the intradermal coccidioidin injection $(\underline{33}, \underline{34})$.

The lesions appear between the first and third week of the onset of the symptoms and they are characterized by subcutaneous, erythematous, painful nodules, localized in the pretibial zone. Diagnosis is clinical, but if a biopsy is obtained, histology reveals panniculitis with septa inflammation in the subcutaneous fat, usually without vasculitis. It is considered a marker of intact cellular immunity, reason why it represents a good prognosis, with low dissemination risk and death (35). In pregnant women, the presence of erythema nodosum is a marker of good prognosis and recovery, with a lower rate for the need of pharmacological treatment (36).

Acute exanthema: It has also been called toxic erythema, and it is present in 10$26.6 \%$ of patients. It usually appears 48 hours before the onset of the other symptoms and the rising of antibodies in the serum. Clinically, it is characterized by macules, papules, urticarial or target lesions, which are generalized, confluent, associated to pruritus, occasionally severe. It may persist for many weeks and be resolved with descamation in palms and soles. There may be oral compromise (32). The biopsy of the lesions shows unspecified and variable findings, but they usually share the presence of vacuolar interfase dermatitis, spongiosis, and a superficial lymphocytic infiltrate with occasional eosinophiles $(\underline{37}, \underline{38})$.

Erythema multiforme: It has been recognized as a manifestation of coccidioidomycosis for more than 60 years, and it is present in $23 \%$ of patients. It appears at the onset of the symptoms with target lesions, oral compromise, fissures in the lips and pruritus. It is located mainly in the thorax, neck and face. The differentiation between erythema multiforme and acute exanthema with target lesions occasionally may just be done by histopathological study, with the presence of necrotic keratinocytes diagnostic for erythema multiforme $(\underline{16}, \underline{39})$.

Sweet syndrome: The association of acute febrile neutrophilic dermatosis or Sweet syndrome and pulmonary coccidioidomycosis has been reported in three patients. It presents with fever, cough, and target lesions, suggestive of erythema multiforme, but with Sweet syndrome typical histopathology.

There is improvement of the cutaneous lesions and the pulmonary symptoms after five weeks of treatment with antifungals and topical steroids. Oral steroids -usually 
It could be visualized with periodic acid-Schiff (PAS), hematoxylin-eosine and Gomori-Grocott stains. the pillar treatment for Sweet's syndrome associated with other etiologies- should not be used when it is associated to coccidioidomycosis, due to the risk of dissemination of the infection $(\underline{16}, \underline{40})$.

Interstitial granulomatous dermatitis: It has been reported in five patients with sudden appearance of edematous, erythematous or red papules, nodules, and plaques in the trunk and extremities, without ulceration or descamation. It is associated with systemic symptoms (myalgias, arthralgias, and headache). Clinically, they simulate pulmonary coccidioidomycosis with skin dissemination or Sweet syndrome.

The biopsy reveals dermal interstitial inflammation, histiocyte infiltrate, associated to neutrophils and nuclear dust, and additionally, eosinophils, and giant multinucleated cells. In the foci of interstitial granulomatous inflammation, collagen degeneration and increased mucin foci are observed. The cultures of the biopsies are negative. The lesions improve after the recovery of the pulmonary disease $(16,41,42)$.

Interstitial granulomatous dermatitis and Sweet syndrome may simulate disseminated coccidioidomycosis, but the presence of microorganisms in the cultures and histopathological findings distinguish the diseases (16).

\section{Diagnosis}

Biopsy: It could be visualized with periodic acid-Schiff (PAS), hematoxylin-eosine and Gomori-Grocott stains. The spherules are seen as spherical elements with thick walls, 5-60 $\mu \mathrm{m}$, with numerous, small, globular endospores of 2-5 $\mu \mathrm{m}$ in their interior (4). Gomori-Grocott stain is the most useful, in which the fungus turns black, on a green background $(\underline{43}, \underline{44})$. They may be a diagnostic challenge because they can be easily confused with Histoplasma spp., Blastomyces spp. or Cryptococcus spp. (6).

Direct examination: Direct microscopical examination of the secretions (alveolar aspirate, cerebrospinal fluid, exudate) stained with calcofluor-white (which joins the chitin or cellulose of the cell wall) and observed in a fluorescence microscope, allow the visualizing the spherules with a $22 \%$ sensitivity. The $\mathrm{KOH}$ test may be diagnostic when spherules are observed, but even though it is easy to perform, it has lower sensitivity than calcofluor-white stain and requires an experimented observer $(43,44)$. Culture: The fungus may be isolated in many specimens, with respiratory tract secretions being the ones that produce more positive ratios ( $8.3 \%$ in one study), and blood and cerebrospinal fluid cultures the ones with the lowest isolation. Efficacy depends on the clinical presentation and the management of the sample.

The fungus may be isolated in non-selective media (Sabouraud dextrose agar, with or without cycloheximide, potato dextrose agar, sheep blood agar, chocolate agar, brain-heart infusion agar); young colonies are visible after 2-16 days, grayish in color. Later, the culture shows white, fuzzy, dry colonies, that when older take a brown color. If Coccidioides ssp. is found the drug sensitivity study is not performed because no isolates resistant to conventional treatment have been evidenced (43). Laboratory management is of very high risk due to its high biotic potential, reason why it requires third security level laboratory management (2).

Serology: Diagnosis may be done by immunoassay, immunodiffusion, or by complement fixation. IgM (precipitins) serum titer measurements are used, which represent early humoral immune response (first 1-3 weeks), and IgG (complement fixation), which represent delayed humoral immune response. Classically, a polysaccharide 
The risk of recurrence after the therapy with itraconazole and fluconazole is between 15 and $30 \%$, and it is higher when the compromise is meningeal. from the fungus wall is used as an antigen, which reacts with $\lg \mathrm{M}$ (immunodiffusion or immunoassay), and for complement fixation, fungal chitinase, which reacts with $\mathrm{IGg}$, is used.

Complement fixation titers reflect the severity of the disease and they are useful to monitor the response to treatment. High titers (1:32 to 1:64) are associated with a bad prognosis and systemic dissemination. They have a sensitivity that is close to $56 \%$ and they have been used since 1965 as the serological gold standard for diagnosis. False negatives may happen at the onset of the clinical picture or when acute exanthema appears, so in patients with a high degree of clinical suspicion and a negative result, it should be repeated during the next months to document seroconversion ( $\underline{6})$.

The immunoassay has a sensitivity of $83 \%$. If the result is negative, it does not require confirmation, but if it is positive, it requires confirmation with immunodiffusion in agar gel, which has a sensitivity of $71 \%(\underline{43})$.

Intradermoreaction with coccidioidin: It consists of an intradermal injection with 0.1 $\mathrm{ml}$ of a standardized micellar coccidioidin. The cutaneous induration reaction is measured after 48 hours, and it is considered positive when the diameter is $5 \mathrm{~mm}$ or more (43). This is only useful for population studies because it does not distinguish between acute disease and previous exposure to the fungus ( $\underline{6}$ ).

\section{Treatment}

To start treatment, we need to identify the location of the infection, the extension, and the clinical conditions of the patient that might predispose them to a severe or disseminated disease, and to adverse reactions to antifungals (18). Limited pulmonary coccidioidomycosis or pulmonary nodules without growth may only be observed during two years, without the need for treatment, due to the high rate of spontaneous healing.

Primary pulmonary coccidioidomycosis should be treated when the symptoms persist for more than six weeks or when compromise is severe, with treatment duration of three to six months.

Patients with dissemination risk factors (cell immunity compromise, HIV, transplants, diabetes, treatment with tumoural necrosis factor inhibitor drugs, pregnant women during their second or third trimester, and patients from Philippine of Afro-American descent) require fast start treatment and monitoring for at least a year to ensure complete resolution and no complications. In these patients, the treatment should be prolonged to 12-18 months, with an extension in some special cases, such as meningitis, which requires antifungal treatment for life (ㄴ5-48).

The antifungals of choice are fluconazole (47), itraconazole and amphotericin B, with itraconazole being indicated in bone and joint compromise (49), and amphotericin for severe cases (12). Skin compromise should be treated with itraconazole, 400-600 mg/ day for 12-18 months (50). The treatment for meningitis could be done with fluconazole in high doses (100-1200 mg/day) and intrathecal amphotericin B (table 1) (21).

The risk of recurrence after the therapy with itraconazole and fluconazole is between 15 and $30 \%$, and it is higher when the compromise is meningeal (ㅎ). In refractory or drug-intolerance cases, the new triazoles, voriconazole and posaconazole, could be a useful therapeutic option (51). 
Table 1. Coccidioidomycosis treatments

\begin{tabular}{|c|c|c|}
\hline Type & Treatment & Duration \\
\hline Primary pulmonary & $\begin{array}{l}\text { Monitoring in the majority of cases } \\
\text { (3). Fluconazole ( } 400-600 \mathrm{mg} / \mathrm{day}) \text { or } \\
\text { Itraconazole ( } 400 \mathrm{mg} / \mathrm{day}) \text { with risk } \\
\text { factors or prominent symptoms (12). }\end{array}$ & 3-6 months \\
\hline Disseminated (skin, bones) & $\begin{array}{l}\text { Itraconazole or in severe or refractory } \\
\text { cases amphotericin B }(1-1.5 \mathrm{mg} / \mathrm{kg} / \\
\text { day) minimum one year }(12,50) \text {. }\end{array}$ & At least a year \\
\hline Meningeal & $\begin{array}{l}\text { Fluconazole ( } 400-1000 \mathrm{mg} / \text { day) over } \\
\text { a year or Amphotericin B (21), in most } \\
\text { cases for life (6). }\end{array}$ & $\begin{array}{l}\text { Over a year, in most cases for life } \\
\text { (6) }\end{array}$ \\
\hline
\end{tabular}

\section{Conclusion}

Coccidioidomycosis represents an endemic mycosis in certain locations of the American continent, with a broad clinical spectrum that ranges from asymptomatic to disseminated forms. It has a good prognosis with timely and adequate treatment according to the clinical presentation. This mycosis should be considered as presumptive diagnosis in any patient coming from an endemic zone, with an acute pulmonary clinical picture and suggestive skin lesions such as a chancroid form in primary compromise, and nodular or abscess presentations in the disseminated form. It is important to note that the cutaneous lesions may be secondary to the fungal infection or due to a hypersensitivity reaction to the pulmonary infection, which commonly presents as erythema nodosum. This mycosis is more and more frequent in immunosuppressed patients.

\section{References}

1. Murray PR. Medical microbiology. 7th Edition. Philadelphia: Elsevier/Saunders; 2013. 874 p. https://evolve.elsevier.com/cs/product/9780323086929?role=student

2. Bonifaz Trujillo JA. Micología médica básica [Internet]. 2012 [citado 19 de septiembre de 2014]. Recuperado a partir de: http://site.ebrary.com/id/10757986

3. Welsh 0, Vera-Cabrera L, Rendon A, Gonzalez G, Bonifaz A. Coccidioidomycosis. Clin Dermatol. 2012; 30(6):573-91. https://www.ncbi.nlm.nih.gov/pubmed/23068145

4. Filho D, De A. Chapter 2: coccidioidomycosis. J Bras Pneumol. 2009;35(9):920-30. https://www.ncbi.nlm.nih.gov/pubmed/19820819

5. Ampel NM. Coccidioidomycosis: a review of recent advances. Clin Chest Med. 2009; 30(2):241-51, v. https://www.ncbi.nlm.nih.gov/pubmed/19375631

6. Nguyen C, Barker BM, Hoover S, Nix DE, Ampel NM, Frelinger JA, et al. Recent advances in our understanding of the environmental, epidemiological, immunological, and clinical dimensions of coccidioidomycosis. Clin Microbiol Rev. 2013;26(3):505-25. https://www.ncbi.nlm.nih.gov/pubmed/23824371 
7. Murray JF, Mason RJ, editores. Murray and Nadel's textbook of respiratory medicine. 5th ed. Philadelphia, PA: Saunders/Elsevier; 2010. 2 p. http://medishared. org/thread-261.html

8. Colombo AL, Tobón A, Restrepo A, Queiroz-Telles F, Nucci M. Epidemiology of endemic systemic fungal infections in Latin America. Med Mycol. 2011;49(8):78598. https://www.ncbi.nlm.nih.gov/pubmed/21539506

9. Vélez A, Robledo M, Builes M, Tobón AM, Gómez Cl, Upegui JJ, et al. El caso de infecciosas coccidioidomicosis pulmonar informe de un caso autóctono. Med UPB. 1997;16(2):141-7. https://revistas.upb.edu.co/index.php/Medicina/article/ view/1175

10. Jesus Godoy AC. Coccidioidomicosis sistemica: informe de un caso en Colombia. Acta Medica Colomb. 1990;(4):208-211. http://www.actamedicacolombiana. com/anexo/articulos/04-1990-07.pdf

11. McCarty JM, Demetral LC, Dabrowski L, Kahal AK, Bowser AM, Hahn JE. Pediatric coccidioidomycosis in central California: a retrospective case series. Clin Infect Dis Off Publ Infect Dis Soc Am. 2013; 56(11):1579-85. https://www.ncbi.nlm.nih. gov/pubmed/23463637

12. Limper AH, Knox KS, Sarosi GA, Ampel NM, Bennett JE, Catanzaro A, et al. An official American Thoracic Society statement: Treatment of fungal infections in adult pulmonary and critical care patients. Am J Respir Crit Care Med. 2011; 183(1):96128. https://www.ncbi.nlm.nih.gov/pubmed/21193785

13. Bercovitch RS, Catanzaro A, Schwartz BS, Pappagianis D, Watts DH, Ampel NM. Coccidioidomycosis during pregnancy: a review and recommendations for management. Clin Infect Dis Off Publ Infect Dis Soc Am. 2011; 53(4):363-8. https:// www.ncbi.nlm.nih.gov/pubmed/21810749

14. Ampel NM. Coccidioidomycosis in persons infected with HIV type 1. Clin Infect Dis Off Publ Infect Dis Soc Am. 2005; 41(8):1174-8. http://cid.oxfordjournals.org/ content/41/8/1174.long

15. Bayer AS. Fungal pneumonias; pulmonary coccidioidal syndromes (Part I). Primary and progressive primary coccidioidal pneumonias -- diagnostic, therapeutic, and prognostic considerations. Chest. 1981; 79(5):575-83. https://www.ncbi. nlm.nih.gov/pubmed/7014124?dopt=Abstract

16. DiCaudo DJ. Coccidioidomycosis: A review and update. J Am Acad Dermatol. 2006;55(6):929-42. https://www.ncbi.nlm.nih.gov/pubmed/17110216

17. Magill AJ, editor. Hunter's tropical medicine and emerging infectious diseases. Ninth edition. London: Saunders/Elsevier; 2013. 1190 p. http://www.sciencedirect.com/science/book/9781416043904

18. Galgiani JN, Ampel NM, Blair JE, Catanzaro A, Johnson RH, Stevens DA, et al. Coccidioidomycosis. Clin Infect Dis Off Publ Infect Dis Soc Am. 2005; 41(9):1217-23. https://www.ncbi.nlm.nih.gov/pubmed/16206093 
19. Aviles-Salas A, Quintero-Cuadra Y, Cornejo-Juárez P. Coccidioidomicosis extrapulmonar: Presentación de un caso y revisión de la literatura. Rev Chil Infectol. 2007; 24(5):398-401. http://www.scielo.cl/pdf/rci/v24n5/art09.pdf

20. Adam RD, Elliott SP, Taljanovic MS. The spectrum and presentation of disseminated coccidioidomycosis. Am J Med. 2009; 122(8):770-7. https://www.ncbi.nlm. nih.gov/pubmed/19635278

21. Johnson RH, Einstein HE. Coccidioidal meningitis. Clin Infect Dis Off Publ Infect Dis Soc Am. 2006; 42(1):103-7. http://cid.oxfordjournals.org/content/42/1/103. full

22. Arsura EL, Kilgore WB, Caldwell JW, Freeman JC, Einstein HE, Johnson RH. Association between facial cutaneous coccidioidomycosis and meningitis. West J Med. 1998; 169(1):13-6. https://www.ncbi.nlm.nih.gov/pubmed/9682625

23. Blair JE. State-of-the-art treatment of coccidioidomycosis skeletal infections. Ann N Y Acad Sci. 2007; 1111:422-33. https://www.ncbi.nlm.nih.gov/pubmed/17395727

24. Crum-Cianflone NF, Truett AA, Teneza-Mora N, Maves RC, Chun HM, Bavaro MF, et al. Unusual presentations of coccidioidomycosis: a case series and review of the literature. Medicine (Baltimore). 2006; 85(5):263-77. https://www.ncbi.nlm. nih.gov/pubmed/16974211

25. Blair JE. State-of-the-art treatment of coccidioidomycosis: skin and soft-tissue infections. Ann N Y Acad Sci. 2007; 1111:411-21. https://www.ncbi.nlm.nih.gov/ pubmed/17332079

26. Chang A, Tung RC, McGillis TS, Bergfeld WF, Taylor JS. Primary cutaneous coccidioidomycosis. J Am Acad Dermatol. 2003;49(5):944-9. https://www.ncbi.nlm. nih.gov/pubmed/14576689

27. Ondo AL, Zlotoff BJ, Mings SM, Rochester LC, Shanler SD. Primary cutaneous coccidioidomycosis: an incidental finding. Clin Exp Dermatol. 2010;35(3):e42-3. https://www.ncbi.nlm.nih.gov/pubmed/20500173

28. Gildardo JM, Leobardo VA, Nora MO, Jorge OC. Primary cutaneous coccidiodomycosis: case report and review of the literature. Int J Dermatol. 2006;45(2):121-3. https://www.ncbi.nlm.nih.gov/pubmed/16445500

29. García OCR, Treviño MGM, Salazar FG, Alanis JCS. Coccidioidomicosis cutánea primaria en infante. Gac Médica México. 2014; 150(2):175-6. http://www.anmm. org.mx/GMM/2014/n2/GMM 15020142 175-176.pdf

30. Wilson JW, Smith CE, Plunkett OA. Primary cutaneous coccidioidomycosis; the criteria for diagnosis and a report of a case. Calif Med. 1953; 79(3):233-9. https://www.ncbi.nlm.nih.gov/pubmed/13082426

31. Quimby SR, Connolly SM, Winkelmann RK, Smilack JD. Clinicopathologic spectrum of specific cutaneous lesions of disseminated coccidioidomycosis. J Am Acad Dermatol. 1992; 26(1):79-85. https://www.ncbi.nlm.nih.gov/pubmed/1732341 
32. Deus Filho A de, Deus ACB de, Meneses A de O, Soares AS, Lira AL de A. [Skin and mucous membrane manifestations of coccidioidomycosis: a study of thirty cases in the Brazilian states of Piauí and Maranhão]. An Bras Dermatol. 2010; 85(1):45-51. https://www.ncbi.nlm.nih.gov/pubmed/20464086

33. Braverman IM. Protective effects of erythema nodosum in coccidioidomycosis. Lancet. 1999; 353(9148):168. http://www.thelancet.com/pdfs/journals/lancet/ PlIS0140-6736 (05) $\underline{77213-5 . p d f}$

34. Smith CE. Epidemiology of Acute Coccidioidomycosis with Erythema Nodosum («San Joaquin» or «Valley Fever»). Am J Public Health Nations Health. 1940;30(6):600.

35. Mayer APF, Julia A.Biria, Nazila. There Is a Fungus...Among Us. J Womens Health 15409996. 2012:21(7):798-9.

36. Arsura EL, Kilgore WB, Ratnayake SN. Erythema nodosum in pregnant patients with coccidioidomycosis. Clin Infect Dis off Publ Infect Dis Soc Am. 1998; 27(5):1201-3. https://www.ncbi.nlm.nih.gov/pubmed/9827269

37. Kormos WA, Wu CC, Branda JA, Piris A. Case records of the Massachusetts General Hospital. Case 35-2010. A 56-year-old man with cough, hypoxemia, and rash. N Engl J Med. 2010;363(21):2046-54. http://www.nejm.org/doi/full/10.1056/NE$\underline{\mathrm{JMe} 030079}$

38. DiCaudo DJ, Yiannias JA, Laman SD, Warschaw KE. The exanthem of acute pulmonary coccidioidomycosis: Clinical and histopathologic features of 3 cases and review of the literature. Arch Dermatol. 1 de junio de 2006; 142(6):744-6. https:// www.ncbi.nlm.nih.gov/pubmed/16785377

39. Blackwood CL. Rash and fever in an ill-appearing child. Am Fam Physician. 2004; 70(2):361-3. https://www.ncbi.nlm.nih.gov/pubmed/15291095

40. DiCaudo DJ, Ortiz KJ, Mengden SJ, Lim KK. Sweet syndrome (acute febrile neutrophilic dermatosis) associated with pulmonary coccidioidomycosis. Arch Dermatol. 2005; 141(7):881-4. https://www.ncbi.nlm.nih.gov/pubmed/16027305

41. DiCaudo DJ, Connolly SM. Interstitial granulomatous dermatitis associated with pulmonary coccidioidomycosis. J Am Acad Dermatol. 2001;45(6):840-5. https:// www.ncbi.nlm.nih.gov/pubmed/11712027

42. White FN, Zedek DC, Collins DL, Boswell JS. Granuloma annulare arising in association with pulmonary coccidioidomycosis. Dermatol Online J. 2012; 18(3):7. http://escholarship.org/uc/item/30w9846n

43. Carrada-Bravo T. Los métodos de laboratorio en el diagnóstico de la coccidioidomicosis. Rev Chil Infectol Órgano Of Soc Chil Infectol. 2014;31(3):293-7. http:// www.scielo.cl/scielo.php?script=sci_arttext\&pid=S0716-10182014000300007

44. Saubolle MA. Laboratory aspects in the diagnosis of coccidioidomycosis. Ann N Y Acad Sci. 2007;1111:301-14. https://www.ncbi.nlm.nih.gov/pubmed/17363434 
45. Nelson S, Vytopil M. Recurrence of coccidioidal meningitis after discontinuation of fluconazole. JAMA Neurol. 2013;70(12):1586. https://www.ncbi.nlm.nih.gov/ pubmed/24322515

46. Galgiani JN, Catanzaro A, Cloud GA, Higgs J, Friedman BA, Larsen RA, et al. Fluconazole therapy for coccidioidal meningitis. The NIAID-Mycoses Study Group. Ann Intern Med. 1993; 119(1):28-35. https://www.ncbi.nlm.nih.gov/pubmed/8498760

47. Catanzaro A, Galgiani JN, Levine BE, Sharkey-Mathis PK, Fierer J, Stevens DA, et al. Fluconazole in the treatment of chronic pulmonary and nonmeningeal disseminated coccidioidomycosis. NIAID Mycoses Study Group. Am J Med. 1995; 98(3):249-56. https://www.ncbi.nlm.nih.gov/pubmed/7872341

48. Dewsnup DH, Galgiani JN, Graybill JR, Diaz M, Rendon A, Cloud GA, et al. Is it ever safe to stop azole therapy for Coccidioides immitis meningitis? Ann Intern Med. 1996; 124(3):305-10. https://www.ncbi.nlm.nih.gov/pubmed/8554225

49. Galgiani JN, Catanzaro A, Cloud GA, Johnson RH, Williams PL, Mirels LF, et al. Comparison of oral fluconazole and itraconazole for progressive, nonmeningeal coccidioidomycosis. A randomized, double-blind trial. Mycoses Study Group. Ann Intern Med. 2000; 133(9):676-86. https://www.ncbi.nlm.nih.gov/pub$\underline{\mathrm{med} / 11074900}$

50. Treatment of skin disease. Comprehensive Therapeutic Strategies Lebwohl, Lebwohl,. Oxford: Saunders; 2013.

51. Kim MM, Vikram HR, Kusne S, Seville MT, Blair JE. Treatment of refractory coccidioidomycosis with voriconazole or posaconazole. Clin Infect Dis Off Publ Infect Dis Soc Am. 2011; 53(11):1060-6. https://www.ncbi.nlm.nih.gov/pub$\underline{\mathrm{med} / 22045955}$ 